\title{
Physicochemical, Micriobiological and Sensory Characterization of Canned Friche
}

\author{
Sandra Daza-Orsini ${ }^{\# 1}$, Raul Martelo-Gomez ${ }^{\$ 2}$, Piedad M. Montero-Castillo*3

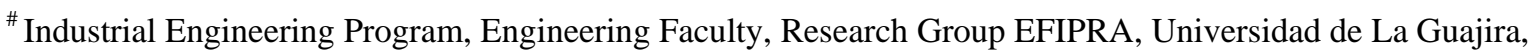 \\ Km.5 Maicao-Riohacha, La Guajira. \\ ${ }^{\$}$ Faculty of Engineering, Research Group INGESINFO, Research GroupGIMATICA, University of Cartagena, \\ Cartagena, Bolívar, Colombia. \\ *Department of Food Engineering, School of Engineering, Research Group NutriciónSalud y \\ CalidadAlimentaria (NUSCA), Universidad de Cartagena, Av. El Consulado, St. 30 No. 48-152. Cartagena de \\ Indias \\ ${ }^{1}$ smdaza@uniguajira.edu.co, ${ }^{2}$ rmartelog@gmail.com, 3 pmargaritamontero@hotmail.com
}

\begin{abstract}
The purpose of this research was to develop of canned friche. This in order to take advantage of the caprine meat which is abundant in the department of La Guajira (Colombia) and that is not very exploited industrially. This was cut and cooked in water, followed fried until golden and canned with different liquid cover. Physicochemical analysis were made in goat meat and the friche in addition to this test were made microbiological and sensory. Goat meat had $79.99 \%$ moisture, $15.9 \%$ protein, $2.23 \%$ fat and $1.88 \%$ ash. Regarding the microbiological results, commercial sterilization was considered satisfactory. Sensory evaluation of the four samples showed no significant difference ( $>>0.05)$ for color, odor and texture parameters, whereas for taste and appearance a significant difference $(p<0.05)$ was found.
\end{abstract}

Keywords_-Goat, La Guajira, liquid cover, goat meat.

\section{INTRODUCTION}

Goats (chivos in spanish) are widely dispersed animals, which have been bred for centuries to supply meat, milk and leather.Because of their small size, adaptability to dry environments and availability, they have been more popular in tropical and subtropical countries and considered a source of meat in these areas[1],[2].It is important to clarify that this meat is an important source of animal protein and low fat[3],[4].

Ovine and caprine meat production in Colombia averages 20.000 tons per year, of which $43 \%$ corresponds to sheep and 57\% of goats[5].La Guajira is the department of Colombia that produces this meat most, with $80.31 \%$ of the goat population of 1124508 animals[6].This department has a large demand from consumers of goat meat and one of the benefits of this meat is through the traditional friche.

Friche is a typical dish of the Department of La Guajira, which is part of the culture of the Wayuu people, which is made from goat meat (not older than 4 months old) cut into cubes.Afterwards it is cooked with salt and water for 20 minutes and then fried until golden brown (approximately 5 minutes). There are variations where goat meat is cooked in its own blood and other ingredients such as paprika, onions, among other things.

In Colombia, the study of goat meat by-products such as friche is of great interest, since it would favour the industrialization of this and other by-products and could also contribute to the scientific and technological strengthening of the region and the country.This can significantly contribute to food security and rural sector development in Colombia[7]. Goat meat research has been extensively studied [4], [8]-[10], and some byproducts have also been studied to a lesser extent by some authors such as[11],[12].

In Colombia and especially in La Guajira there is no adequate use of goat meat, which is consumed fresh without any processing,due to the limited presence of agro-industrial companies engaged in the production and marketing of by-products of this meat that meet hygienic and sanitary conditions to offer a high quality product that provides and guarantees the benefits in terms of food safety.Therefore, the objective of this research was to develop a canned meat product friche type from goat meat, in order to give an added value to this type of elaboration.

\section{A. Canned friche preparation}

\section{MATERIALS AND METHODS}

Goat meat from the hind legs was used, these were prevented from a local market in the city of Riohacha (La Guajira), these were purchased and transferred properly refrigerated to the pilot plants of the University of Magdalena headquarters Taganga (Magdalena-Colombia), where they were weighed and deboned.It was then cut into cubes of $5 \mathrm{~cm}(10 \mathrm{~g})$ and then submitted to an immersion curing process with the addition of $24 \%$ water, $0.35 \%$ nitro salt and $1 \%$ sodium chloride, a process that lasted 24 hours $4^{\circ} \mathrm{C}$. Afterwards it was boiled with salt and water for 20 minutes and then fried until golden brown (approximately $5 \mathrm{~min}$ ). 
For filling the cans, tinplate containers (307 $\times 113$ inches) were used, adding friche to obtain a net weight of $90 \mathrm{~g}$, followed by the addition of packing liquids (M1 $=100 \%$ olive oil, M2 $=100 \%$ palm oil, M3 $=100 \%$ water and M4 $=50 \%$ olive oil $+50 \%$ palm oil) to reach a total weight of $180 \mathrm{~g}$ and leave a head space.The cans were sealed by an automatic Etayo Jimenez SudrySudry (Andosilla-Spain) automatic sealer, then sterilized in an autoclave Cap 2319k automatic digital control autoclave (Bogota-Colombia), which was given at $115^{\circ} \mathrm{C}$ for one hour. The cans were then cooled by spraying at $30^{\circ} \mathrm{C}$, and the cans were stored at the same temperature.

\section{B. Physicochemical analysis}

Both the raw material (goat meat) and the finished product were tested for moisture (952.08), protein (928.08), fat (948.15), ash (938.06) and $\mathrm{pH}$ with $\mathrm{pH}$-meter wtw $\mathrm{pH}$ 315i/set (Weilheim-Germany), all according toAOAC[13].

\section{Microbiological Analysis}

These analyses were carried out following the methodology recommended by NTC 4433 [14], with which the commercial sterility test of the finished product was determined.

\section{Sensory analysis}

It was carried out through a hedonic scale with scores from 1 for "I dislike very much" to 9 for "I like it very much" in order to evaluate the attributes of flavor, color, smell, texture and appearance. The answer was given by 20 untrained panelists, each presented four samples of $10 \mathrm{~g}$ of friche after being canned, coded with nomenclature M1, M2, M3 and M4.

\section{E. Statistical analysis}

In this research we considered a unifactorial design of 4 levels, with 3 repetitions (12 experimental units). The multiple comparison of stockings was made by Tukey's test. All statistical analyses were performed with a 95\% confidence level; data were processed using the ANOVA procedure, using the minitab ${ }^{\circledR} 17$ statistical package.

\section{A. Physicochemical analysis for goat meat and friche meat}

\section{RESULTS AND DISCUSSIONS}

The protein content of goat meat (Table 1) was found in the range shown byArainet al.,[15], who obtained a protein range of $13.12 \%-17.50 \%$ in goat meat less than 7 months old. As for fat content, it was found to be within the range of fat found by some researchers[8],[15],[16], this low fat content might be due to age (less than 4 months) as indicated[17].

Table 1. Physicochemical analysis of goat meat

\begin{tabular}{|l|c|}
\hline \multicolumn{1}{|c|}{ Parameter } & Quantity \\
\hline Moisture & $79.9 \%$ \\
\hline Protein & $15.9 \%$ \\
\hline Fat & $2.23 \%$ \\
\hline Ash & $1.88 \%$ \\
\hline $\mathrm{pH}$ & 5.7 \\
\hline
\end{tabular}

The moisture content of fresh goat meat is high value that is comparable to that shown by[15], in goat meat under 7 months which obtained a moisture range in different samples of $76.60 \%-80.02 \%$, characteristic that makes it quickly susceptible to microorganisms and can be catalogued as a perishable product,due to the water content of its structure, which is why it is necessary to look for a method of conservation that allows the useful life of this raw material to be extended.The percentage of ashes was higher than those found by several authors [3],[18], [19]. The percentage of ashes is different between goats raised in stables and goats kept in open fields, where the mineral content tends to vary [1].

On the other hand, the $\mathrm{pH}$ of the meat was 5.7 confirming that it is a meat of good quality and optimal for processing because the bacteriological stability of the meat is a factor dependent on the $\mathrm{pH}$, this in the meat generally varies from 5.6 to 5.7 , the $\mathrm{pH}$ greater than 6 is prohibited consumption of meat with an alkaline reaction because it is highly susceptible to microbial deterioration[16].

During frying there were significant changes in humidity, mainly because it is considered a process of rapid dehydration[20], in which part of the water possessed by the food was evaporated in stages 2 and 3 of frying[21], in turn, the percentage of fat increased due to the fact that at the time of evaporating the water is concentrated.

For the four friche formulations canned using different packing liquids, physicochemical tests were performed, the results can be seen in Table 2. A Tukey test was then performed to establish if there was a difference between the stockings. 
In terms of moisture and fat levels (Table 2$)$, a significant difference $(p<0.05)$ was found between the M3 formulation, which obtained the highest percentage of moisture and the lowest percentage of fat, and the rest of the formulated formulations. This characteristic is conferred by the greater proportion of water in this formulation. The water content in M3 was higher because the sample had water coverage liquid and absorbed a percentage of it, since the friche had common salt $(\mathrm{NaCl})$, which can help to absorb the water as indicated[22]; fat absorption was also observed in the other samples (M1, M2 and M4).

Table 2. Physicochemical analysis of friche with different types of covering fluid

\begin{tabular}{|l|c|c|c|c|}
\hline & M1 & M2 & M3 & M4 \\
\hline Moisture (\%) & $50.77 \pm 1.24^{\mathrm{a}}$ & $51.93 \pm 0.51^{\mathrm{a}}$ & $56.80 \pm 0.3^{\mathrm{b}}$ & $51.20 \pm 0.95^{\mathrm{a}}$ \\
\hline Protein(\%) & $16.77 \pm 1.04^{\mathrm{a}}$ & $16.53 \pm 0.20^{\mathrm{a}}$ & $16.30 \pm 0.6^{\mathrm{a}}$ & $16.17 \pm 0.45^{\mathrm{a}}$ \\
\hline Fat (\%) & $4.38 \pm 0.41^{\mathrm{a}}$ & $4.69 \pm 0.54^{\mathrm{a}}$ & $3.12 \pm 0.07^{\mathrm{b}}$ & $4.63 \pm 0.49^{\mathrm{a}}$ \\
\hline Ash (\%) & $1.22 \pm 0.12^{\mathrm{a}}$ & $1.34 \pm 0.22^{\mathrm{a}}$ & $1.32 \pm 0.09^{\mathrm{a}}$ & $1.22 \pm 0.05^{\mathrm{a}}$ \\
\hline
\end{tabular}

*Different letters in the same column indicate significant statistical differenceAverage \pm standard deviation

For protein and ash content there was no significant difference ( $>0.05)$ for the different formulations. This is due to the indications given byRees and Bettison[23], who say that the amount of crude protein appears to be almost modified as a result of heat treatment (sterilization), and that the minerals (ash) are stable to heat preservation treatments such as sterilization.

\section{B. Microbiological Analysis}

Sterility results showed that for M1, M2, M3 and M4 formulations there was no growth of anaerobic or aerobic microorganisms at $35^{\circ} \mathrm{C}$ and $55^{\circ} \mathrm{C}$. In accordance with NTC 4433 of 2006[14], all formulations used in this investigation for not having growth in any of the conditions are considered to have had a satisfactory commercial sterility test.

Thanks to the correct sterilization, the preservation and safety for consumption of the four formulations is ensured, as indicated by several authors[24]-[26].

\section{Sensory analysis}

As for the assessment of the sensory characteristics of friche, the color, odor and texture attributes were not significantly different ( $>0.05$ ) in each of the formulations (Table 3), which indicates that the covering liquid did not have much influence on these parameters.In contrast, a significant difference was detected in taste and appearance attribute $(\mathrm{p}<0.05)$, where M1, M2 and M4 formulations differed from M3. This due to the friche absorbed during storage, sensory properties of the covering liquid as indicatedIhobe [27],

Olive oil as a covering liquid, the M1 formulation obtained the best scores thanks to its microcomponents because they improve certain parameters such as colour, taste and appearance[28].

Table 3. Multiple average comparison by Tukey test

\begin{tabular}{|l|c|c|c|c|c|}
\hline Treatment & Flavor & Color & Odor & Texture & Appearance \\
\hline M1 & $9.0^{\mathrm{a}}$ & $8.3^{\mathrm{a}}$ & $8.75^{\mathrm{a}}$ & $8.55^{\mathrm{a}}$ & $8.875^{\mathrm{a}}$ \\
\hline M2 & $8.6^{\mathrm{a}}$ & $8.2^{\mathrm{a}}$ & $8.25^{\mathrm{a}}$ & $7.88^{\mathrm{a}}$ & $7.875^{\mathrm{ab}}$ \\
\hline M3 & $7.0^{\mathrm{b}}$ & $8.0^{\mathrm{a}}$ & $7.87^{\mathrm{a}}$ & $8.22^{\mathrm{a}}$ & $7.625^{\mathrm{b}}$ \\
\hline M4 & $8.4^{\mathrm{a}}$ & $8.0^{\mathrm{a}}$ & $8.37^{\mathrm{a}}$ & $8.37^{\mathrm{a}}$ & $7.875^{\mathrm{ab}}$ \\
\hline
\end{tabular}

*Different letters in the same column indicate significant statistical difference

The high results shown in this research are similar to those shown byCajo and Ipanaqué[12] and Alfaro [29], who evaluated fried goat meat and canned goat meat in a local sauce, respectively, where the results shown by the evaluators were very favorable.

\section{CONCLUSION}

Thanks to the great advantages that goat meat has, such as being low in fat and rich source of protein, it can be used in the elaboration of products to give it an added value and boost its consumption. From the 4 formulations it was proved that the best sensory results were M1, which had friche and olive oil as the covering liquid.

\section{ACKNOWLEDGEMENTS}

The authors acknowledge the help that the University of Magdalena Taganga headquarters had in giving up the space of the pilot plants to develop the practical part of this project. 


\section{REFERENCES}

[1] M. Madruga, F. Resosemito, N. Narain, W. Souza, M. Cunha and J. Ramos,"Effect of raising conditions of goats on physico-chemical and chemical quality of its meat,”Ciencia y TecnologíaAlimentaria, vol. 5, no. 2, pp. 100-104, 2006.

[2] A.R. Sen, A. Santra and S.A. Karim,"Carcass yield, composition and meat quality attributes of sheep and goat under semiarid conditions,”Meat Science, vol. 66, no. 4, pp. 757-763, 2004.

[3] E. Webb, N. Casey and L. Simela,“Goat meat quality,” Small Ruminant Research, vol. 60, no. 1, pp. 153-66, 2005.

[4] R. Peña, D. Duran, L. Baleta-Medrano and J. Gualdrón,"Efecto del marinado con NaCl y Tripolifosfato-sódico sobre las propiedades microbiológicas y la terneza de la carne de cabra,” Revista speiDomus, vol. 8, no. 17, pp. 22-30, 2012.

[5] Ministerio de agricultura y desarrollo rural (Minagricultura). Cadena Ovino-Caprina recibirá asistencia técnica binacional para conquistar mercado canadiense, disponible en: https://www.minagricultura.gov.co/noticias/Paginas/Cadena-Ovino-Caprina.aspx, 2014.

[6] Instituto Colombiano Agropecuario (ICA). Censo pecuario nacional 2016, disponible en: http://www.ica.gov.co/getdoc/8232c0e5be97-42bd-b07b-9cdbfb07fcac/Censos-2008.aspx, 2016.

[7] Ministerio de agricultura y desarrollo rural (Minagricultura). Acuerdo nacional de competitividad, Cadena productiva ovino-caprina nacional, disponible en: https://sioc.minagricultura.gov.co/OvinoCaprina/Documentos/004\%20\%20Documentos\%20Competitividad\%20Cadena/Nuevo\%20Acuerdo\%20Nacional\%20de\%20Competitividad\%202012.pdf, 2012.

[8] F. Longobardi, D. Sacco, G. Casiello, A. Ventrella, A. Contessa and A. Sacco, “Garganica kid goat meat: Physico-chemical characterization and nutritional impacts,” Journal of food composition, vol. 28, no. 2, pp. 107-113, 2012.

[9] S.H. Choi, Y.H. Choy, Y.K. Kim and S.N. Hur,"Effects of feeding browses on growth and meat quality of Korean Black Goats," Small Ruminant Research, vol. 65, pp. 193-199, 2006.

[10] K. Qwele, A. Hugo, S.O.Oyedemi, B. Moyo, P.J. Masika and V. Muchenje,“Chemical composition, fatty acid content and antioxidant potential of meat from goats supplemented with Moringa (Moringaoleifera) leaves, sunflower cake and grass hay,” Meat Science, vol. 93, pp. 455-462, 2013.

[11] Y.P. Gadekarb, B.D. Sharmaa, A.K. Shindeb, A.K. Vermac and S.K. Mendiratta, "Effect of natural antioxidants on the quality of cured, restructured goat meat product during refrigeratedstorage $\left(4 \pm 1^{\circ} \mathrm{C}\right)$,"Small Ruminant Research, vol. 119, pp. 72-80, 2014.

[12] F. Cajo and H. Ipanaqué,"Efecto del tratamiento térmico sobre la firmeza, sabor y aceptabilidad general del enlatado de carne de cabrito (Caprahircus) en salsa de loche (Cucurbitamoschata),” Rev. Ingeniería: Ciencia, Tecnología e Innovación,vol. 3, no. 2, pp. 134144, 2016.

[13] AOAC. Official Methods of Analysis of the AOAC International, 16th ed. Association of OfficialAnalyticalChemists, International, Gaithersburg, MD, 1995.

[14] Norma técnica colombiana (NTC) 4433, Método para evaluar la esterilidad comercial en alimentos, 2006.

[15] M.A. Arain, M. Khaskheli, I.R. Rajput, S. Faraz, S. Rao, M. Umer and K. Devrajani,“Effect of Slaughtering Age on Chemical Composition of Goat Meat,”Pakistan Journal of Nutrition, vol. 9, no. 4, pp. 404-408, 2010.

[16] A. Sebsibe, "Sheep and Goat Meat Characteristics and Quality,” chapter 12, Sheep and Goat Production Handbook for Ethiopia, Ethiopia Sheep and Goat Productivity Improvement Program (ESGPIP), 2008, pp. 328-340.

[17] M.S. Madruga, S.G.B. Arruda, E.M. Araújo, L.T. Andrade, J.C. Nascimento and R.G. Costa,"Efeito da idade de abate no valor nutritivo e sensorial da carne caprina de animais mestiços,"Food Science and Technology (Campinas), vol. 19, no. 3, pp. 374-379, 1999.

[18] J.H. Lee, B. Kouakou and G. Kannan,"Chemical composition and quality characteristics of chevon from goats fed three different postweaning diets,” Small Ruminant Research, vol. 75, pp. 177-184, 2008.

[19] V. Tomovic, M. Jokanovic, J. Švarc-Gajic, I. Vasiljevic, B. Šojic, S. Škaljaca, I. Pihler, V. Simin, M. Krajinovic and M. Žujovic,"Physical characteristics and proximate and mineral composition of Saanen goat male kids meat from Vojvodina (Northern Serbia) asinfluenced by muscle,” Small Ruminant Research, vol. 145, pp. 44-52, 2016.

[20] H. Wu, S. Tassou, T. karayiannis and H. Jouhara,"Analysis and simulation of continuous food frying processes," Applied Thermal Engineering, vol. 53, no. 2, pp. 332-339, 2013.

[21] D. Tirado, D. Acevedo and L. Guzmán,“Freído por inmersión de los alimentos,” Revista ReCiTeIA, vol. 12, no. 1. pp. 72-80, 2012.

[22] I. Muñoz, N. Garcia-Gil, J. Arnau and P. Gou, “Rehydration kinetics at 5 and 15 C of dry salted meat,” Journal of Food Engineering, vol. 110, no. 3, pp. 465-471, 2012.

[23] J Reesand J. Bettison,“Procesado térmico y envasado de alimentos,” Editorial Acribia, Zaragoza, España, 1994, p. 287.

[24] M. Farid and A.G. Ghani,“A new computational technique for the estimation of sterilization time in canned food,” Chemical engineering and processing, vol. 43, pp. 523-531, 2004.

[25] A.A. Teixeira and G.S. Tucker, “On-line retort control in thermal sterilization of canned foods,” Food Control, vol. 8, no. 1, pp. 13-20, 1997.

[26] S. Syafiie, F. Tadeo, M. Villafin and A.A. Alonso,"Learning control for batch thermal sterilization of canned foods,” ISA Transactions, vol. 50, no. 1, pp. 82-90, 2011.

[27] Ihobe. Libro blanco para la minimización de residuos y emisiones: Conservas de pescado, Gobierno Vasco, 1999, p. 40

[28] M. Servili, R. Selvaggini, S. Esposto, A. Taticchi, G. Montedoro and G. Morozzi,"Health and sensory properties of virgin olive oil hydrophilic phenols: Agronomic and technological aspects of production that affect their occurrence in the oil," Journal of Chromatography A, vol. 1054, no.24, pp. 113-127, 2004.

[29] S. Alfaro, M. Jiménez, D. Braña, M. Torres and O. Del Razo,“Evaluación sensorial de la carne de cabra y cabrito,” Instituto de ciencias agropecuarias, Universidad Autónoma del estado de Hidalgo, México D.F., México. pp. 64-68, 2013. 